\title{
Cytokines and sympathy: the control of regulatory $T$ cells
}

This article was published in the following Dove Prees journal: International Journal of Interferon, Cytokine and Mediator Research 14 April 2010

Number of times this article has been viewed

\section{Robert E Cone Sourojit Bhowmick \\ Department of Immunology, Connecticut Lions Vascular Vision Center, University of Connecticut Health Center, Farmington, CT, USA}

Correspondence: Robert E Cone Department of Immunology, Connecticut Lions Vascular Vision Center, University of Connecticut Health Center, Farmington, CT, USA 06030-3105

Tel + I 8606793611

Fax +I 8606792936

Email cone@uchc.edu
Abstract: To ensure protection from external invaders, mitigate collateral damage from immune reactions, and prevent immune system responses against self, the immune response is highly regulated by the sympathetic nervous system, cytokines, together with both adaptive and innate regulatory $\mathrm{T}$ cells. Moreover, the generation and function of adaptive and innate regulatory $\mathrm{T}$ cells is also under strong regulation by the sympathetic nervous system. Here we consider modulation of regulatory $\mathrm{T}$ cells by the sympathetic nervous system and cytokines that could lead to strategies for the enhancement of an immune response, or the prevention or mitigation of autoimmune diseases.

Keywords: immunoregulation, regulatory $\mathrm{T}$ cells, cytokines, sympathetic nervous system

\section{“A well-regulated militia" (US Bill of Rights)}

The immune system of "higher" vertebrates has evolved as a powerful protective force that protects the host from invaders, both foreign and domestic. Although the immune system is selective in its response to immunogens, "collateral damage" to healthy tissue can occur. Accordingly, like any defense organization in a complex society, the immune system must be highly regulated. Such regulation occurs at several levels:

- The elimination of self-reactive lymphocytes during development.

- The creation of "immune privileged" sites where immune reactions are less likely to occur. Such sites are particularly critical for sensitive tissue such as the eye and the brain.

- The generation of regulatory cells that eliminate or inhibit cells that respond to self antigens.

Therefore, regulatory $\mathrm{T}$ cells are a defense organization within a defense organization. Although many cells of the immune system can perform a regulatory function, there are essentially three $\mathrm{T}$ cell types that comprise the "adaptive" regulatory (cell) system (Table 1): $\mathrm{CD}^{+}, \mathrm{CD} 25^{+} \mathrm{T}$ cells that express the forkhead box P3 transcription factor (FoxP $3^{+}$, regulatory $\mathrm{T}$ Cells [Treg]), $\mathrm{T}$ cells expressing a marker for "natural killer" cells (NKT cell) and $\mathrm{CD}^{+} \mathrm{T}$ cells. The induction, function and properties of these cells has been recently reviewed extensively. ${ }^{1-4} \mathrm{CD} 4+$, FoxP3 ${ }^{+} \mathrm{T}$ cells occur without antigenic stimulation (so-called natural Treg) and are also induced by transforming growth factor- $\beta$ (TGF- $\beta$ ). The suppression mediated by CD4, FoxP3 ${ }^{+} \mathrm{T}$ cells is not antigen-specific and requires sensitivity to TGF- $\beta$ (please see below). Regulatory NKT cells and $\mathrm{CD} 4^{+}$ $\mathrm{T}$ cells, induced by antigen participate in the activation of $\mathrm{CD} 8^{+}$regulatory $\mathrm{T}$ cells, that are antigen-specific and, (unlike $\mathrm{CD}^{+}, \mathrm{FoxP}^{+}$Treg), suppress "activated" $\mathrm{T}$ cells. 
Table I Immunoregulatory T cells ${ }^{1-4}$

\begin{tabular}{|c|c|c|c|c|}
\hline Cell & $\begin{array}{l}\text { Antigen } \\
\text { specificity }\end{array}$ & $\begin{array}{l}\text { Induce } \\
\text { CD8 Treg }\end{array}$ & Restriction & Cytokines \\
\hline $\begin{array}{l}\text { CD4/CD25 } \\
\text { FoxP3 }\end{array}$ & - & $+1-$ & - & TGF- $\beta$ \\
\hline NKT &,+- & + & CDI & $\begin{array}{l}\text { TGF- } \beta \text { IL-4 } \\
\text { IL- } 10\end{array}$ \\
\hline CD4 & + & + & MHC II & $\begin{array}{l}\text { TGF- } \beta \\
\text { IL-10 }\end{array}$ \\
\hline CD8 & + & - & Qa-I & TGF- $\beta$ \\
\hline
\end{tabular}

Abbreviations: NKT, natural killer T cells; TGF- $\beta$, transforming growth factor- $\beta$; MHC, major histocompatibility complex; IL, Interleukin.

$\mathrm{CD}^{+}$regulatory $\mathrm{T}$ lymphocytes were first described in the 1970's. ${ }^{5,6}$ Ironically today, CD8 ${ }^{+}$regulatory T cells are considered a relatively new and incompletely understood group of regulatory $\mathrm{T}$ cells whose function is still being unraveled. These cells are subject to regulatory influences known to impact on $\mathrm{T}$ and $\mathrm{B}$ lymphocytes that affect protective defense mechanisms. Moreover, regulatory $\mathrm{T}$ cells may be expanded during an immune response and since some of these cells are specific to the inducing antigen, these antigen-specific regulatory $\mathrm{T}$ cells, can make a specific "pre-emptive response" to prevent a potentially damaging immune response. In that regard, such a regulatory response can be a "double-edged sword" as pointed out by the late JW Streilein. ${ }^{7}$ Therefore, like any immune response, the regulatory response must be finely balanced for effective results that do not compromise protection. To date, such "regulation of the regulators" is becoming apparent. Factors that regulate the immune system in general, impact on the regulatory immune system. Within the host, these factors may be derived from the immune system itself and/or influences "external" to the immune system.

In addition to physiological factors that influence all aspects of function (eg, nutrition), the immune system is regulated internally by itself, through regulatory cells and cytokines, and externally by the central and peripheral nervous system..$^{9-16}$ Although the influence of the sympathetic nervous system (SNS) and cytokines on the effector immune system has been reviewed extensively, ${ }^{9-13}$ here we consider SNS-regulatory $\mathrm{T}$ cell interactions and the influence of cytokines on "regulatory T cells," as these impact on overall immune homeostasis.

\section{Sympathetic regulation of regulatory $T$ cells}

Cells that participate in adaptive and "natural" immunity express receptors for neuropeptides, ${ }^{9,12,13}$ suggesting that sympathetic neuropeptides could influence the immune response. The influence of the SNS on the immune response has been demonstrated by ablation of peripheral sympathetic neurons by the neurotoxin 6-hyrdoxydopamine (6-OHDA) that when administered peripherally depletes norepinephrine (NE) levels in the lymphoid organs by more than 90\%. ${ }^{9,10,12}$ Since 6-OHDA does not cross the blood brain barrier (BBB), ${ }^{10,14}$ peripheral administration does not cause any reduction in the levels of central nervous system (CNS) catecholamines, although peripheral catecholamine levels are depleted. Peripheral administration of 6-OHDA enhances the production of some antibodies. ${ }^{15-17}$ Although the production of cytokines that promote cell-mediated immunity may be affected by chemical sympathectomy, ${ }^{12,16-20}$ the activation of cells that effect delayed-type hypersensitivity (DTH) in mice may not be affected by acute sympathectomy with 6-OHDA. ${ }^{17,18}$ However, the DTH reaction exemplified by the swelling of tissue that follows challenge with antigen does not occur in 6-OHDA-treated mice. ${ }^{17,18}$ Therefore the lack of swelling at the site challenged by the antigen in immunized, 6-OHDA-treated mice ${ }^{17,18}$ may be due to the influence of the SNS on the vascular exchange of fluids. ${ }^{21}$

The injection of 6-OHDA directly into the CNS of rats induces cells that transfer the suppression of humoral immunity, or induces an increase in $\mathrm{OX}^{+}$cells concomitant with the suppression of experimental autoimmune encephalomyelitis (EAE). ${ }^{22}$ Peripheral administration of 6-OHDA prevents the generation of antigen-specific $\mathrm{CD} 8^{+}$splenic regulatory $\mathrm{T}$ cells induced by an injection of antigen into the anterior chamber. ${ }^{17}$ The number of regulatory hepatic NKT cells are diminished in 6-OHDA- treated mice ${ }^{17,24}$ as well as the ability of thymic NKT cells to induce the generation of splenic $\mathrm{CD}^{+}$regulatory $\mathrm{T}$ cells after the injection of antigen into the anterior chamber of an eye. ${ }^{17}$ Because the maintenance of hepatic NKT cells requires $\mathrm{NE},{ }^{24}$ the loss of $\mathrm{NE}$ due to sympathectomy with 6OHDA should impact on thymic and peripheral NKT cells that are necessary to induce the $\mathrm{CD}^{+}$regulatory $\mathrm{T}$ cells after the intracameral injection of an antigen. ${ }^{25} \mathrm{~A}$ recent report ${ }^{26}$ demonstrated the selective removal of sympathetic innervation of the eye, by surgical removal of the cervical sympathetic ganglion, reduced levels of TGF- $\beta$ in the aqueous humor and prevented the induction of suppression of delayed-type hypersensitivity, induced by an intracameral injection of antigen. Here the sympathectomy is localized to the eye suggesting that the elimination of ocular sympathetic innervation affects a site that generates circulating cells that induce the activation of peripheral $\mathrm{CD} 8^{+}$regulatory $\mathrm{T}$ cells.

The influence of the SNS on regulatory T cells could be direct via $\mathrm{NE},{ }^{12,20,22}$ neuropeptide $\mathrm{Y}^{27}$ or tissue plasminogen 
activator (tPA) $)^{28}$ by converting inactive plasminogen into plasmin that modulates inflammation (Figure 1). Because chemical sympathectomy with 6-OHDA prevented the generation of antigen-specific $\mathrm{CD} 8^{+}$regulatory $\mathrm{T}$ cells induced by the intracameral injection of antigen, ${ }^{17}$ we investigated the effect of systemic sympathectomy of mice on the number and activity of peripheral $\mathrm{CD}^{+}{ }^{+}$, $\mathrm{FoxP}^{+}$Treg. ${ }^{18}$ Two days after the injection of 6-OHDA recipient mice had a nearly two-fold increase in functional splenic and lymph node $\mathrm{CD}^{+}{ }^{+} \mathrm{FoxP}^{+}$regulatory cells. This increase in splenic and lymph node Treg appears to be due to an increase in TGF- $\beta$ in the spleen and lymph nodes because 6-OHDA treatment did not induce an increase in $\mathrm{CD}^{+}$, FoxP $3^{+}$Treg in mice resistant to TGF- $\beta$. Moreover, the induction of EAE is inhibited or reduced in mice that received 6-OHDA before immunization with the encephalitogenic myelin oligodendrocyte glycoprotein (MOG) peptide 35-55. CD4 ${ }^{+}$, FoxP3 ${ }^{+}$Treg recovered from mice that received 6-OHDA reduced the induction of EAE. ${ }^{18}$ These observations are consistent with those demonstrating that Tregs express tyrosine hydroxylase and catecholamines. ${ }^{29}$ Moreover, the latter report showed a catecholamine-dependent reduction in Treg. That chemical sympathectomy has also been reported to inhibit or enhance EAE could be due to the timing of sympathectomy versus immunization. An increase in $\mathrm{CD}^{+}$, FoxP3 ${ }^{+}$Treg at the time of, or before immunization, would inhibit the induction of EAE. However, inhibition of the induction of $\mathrm{CD}^{+}$Treg could enhance EAE because this population of regulatory $\mathrm{T}$ cells more effectively suppresses activated $\mathrm{T}$ cells.

\section{Cytokine regulation of regulatory T cells}

Communication between the many elements of the immune system is a function (in part) of cytokines and chemokines produced by immunocytes and other cells. These cytokines could influence "natural" regulatory T cells that are present without an apparent immune response. Additionally, some cytokines could amplify the number or activity of regulatory $\mathrm{T}$ cells. For example, interleukin (IL)-2 could amplify Treg or effector $T$ cells because most activated cells express receptors for IL-2. However, CD4 or CD8 ${ }^{+}$effector T cells induced/ amplified by an immune response can also be "converted" to a regulatory phenotype in vitro by TGF- $\beta .^{30,33}$ Accordingly, the entry of $\mathrm{CD}^{+}$effector $\mathrm{T}$ cells into the anterior chamber of an eye may "convert" some of the effector cells to a Treg phenotype because of the TGF- $\beta$ in the aqueous humor

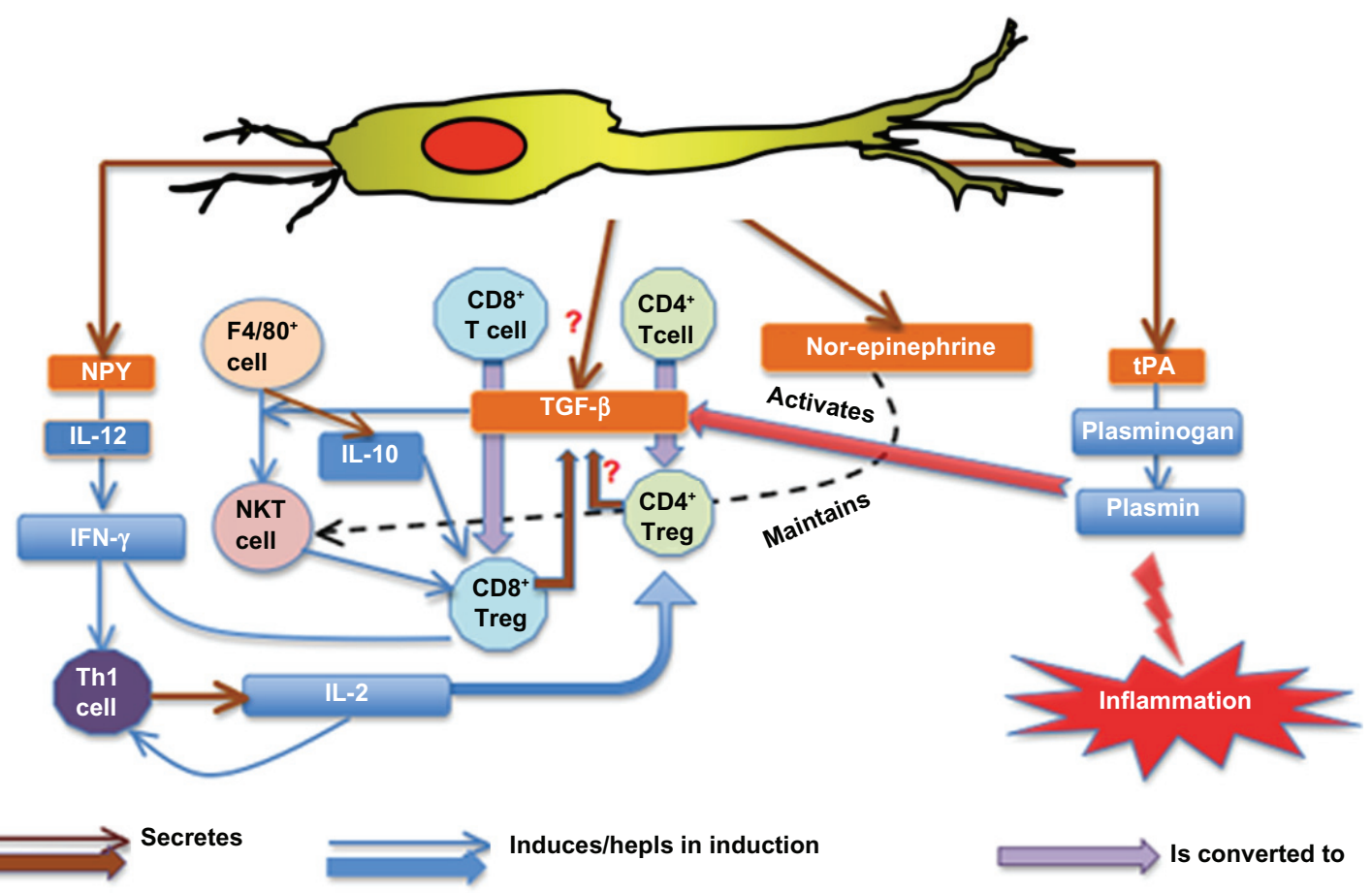

Figure I Influence of the sympathetic nervous system and cytokines on effector and regulatory T cells. Sympathetic neurons are a source of neuropeptide Y (NPY) and norepinephrine that influence regulatory $T$ cells and effector $T$ cells directly or indirectly through an influence on the production of cytokines that influence the production of IFN- $\gamma$. Norepinephrine may influence directly effector T cells, regulatory T cells such as NKT cells, B cells and antigen presenting cells. Norepinephrine may also influence the production of TGF- $\beta$ by other cells. Tissue plasminogen activator (tPA) converts plasminogen to plasmin that plays a role in inflammation. 
(please see below). The effects of cytokines on regulatory $\mathrm{T}$ cells has been reviewed extensively. ${ }^{34,35}$ Table 2 summarizes these effects although the data is not all-inclusive. The influence of cytokines on regulatory $\mathrm{T}$ cells is factored into activation/conversion or effector function. Most cytokines have a positive stimulating or supportive effect although some downregulate the regulatory cell. Here care should be taken as to whether the downregulation effect is on the regulatory cell or does the cytokine render the effector cell "target" resistant to suppression.

\section{Direct conversion of effector $T$ cells to regulatory $T$ cells}

Treatment of CD4 or CD8 ${ }^{+}$effector T cells with TGF- $\beta$ in vitro "converts" these cells to a regulatory phenotype..$^{30-33,34}$ The increase in mRNA for TGF- $\beta$ in lymph nodes and spleen in 6-OHDA-treated mice is associated with the increase in $\mathrm{CD}^{+}$, FoxP3 ${ }^{+}$Treg in these organs. ${ }^{18}$ The exposure of $\mathrm{CD}^{+}{ }^{+}$effector $\mathrm{T}$ cells to TGF- $\beta$ and $\alpha$-melano stimulating hormone in aqueous humor may well convert these cells to CD4, FoxP3 ${ }^{+}$regulatory T cells. ${ }^{36}$ This conversion could occur in any immune privileged site that contains TGF- $\beta$ or in the presence of TGF- $\beta$-producing cells such as some tumor cells. Similarly, IL-17, in conjunction with TGF- $\beta$ also promotes the conversion of effector T cells to a Treg phenotype. ${ }^{30}$ Additionally, $\mathrm{CD} 8^{+}$cytotoxic $\mathrm{T}$ cells are "converted" to a regulatory phenotype by incubation in vitro with TGF- $\beta{ }^{31-33}$ However, such a "conversion" in vivo has not been demonstrated. Although TGF- $\beta$ converts effector $\mathrm{T}$ cells to a regulatory phenotype, regulatory $\mathrm{T}$ cells can be generated in vivo in mice resistant to TGF- $\beta .{ }^{37}$ Therefore, $\mathrm{T}$ cell sensitivity to TGF- $\beta$ is not obligate to generate regulatory $\mathrm{T}$ cells. However, effector $\mathrm{T}$ cell sensitivity to TGF- $\beta$ is required for the effector cells to be suppressed by $\mathrm{CD}^{+}$regulatory $\mathrm{T}$ cells themselves induced by the intracameral injection of antigen ${ }^{37}$ and by CD4, FoxP3 ${ }^{+}$ regulatory $\mathrm{T}$ cells. ${ }^{38}$ Although the suppressive mechanism of $\mathrm{CD} 4$, FoxP3 ${ }^{+}$regulatory $\mathrm{T}$ cells is not clear, direct evidence suggests that TGF- $\beta$ is a suppressive mechanism for some $\mathrm{CD}^{+}$regulatory T cells. ${ }^{37,39,40}$ In addition to TGF- $\beta$, agonist antibodies to $4-1 \mathrm{BB}$ "convert" $\mathrm{CD} 8^{+}$cytotoxic $\mathrm{T}$ cells to a suppressor phenotype that suppress other $\mathrm{T}$ cells by the production of TGF- $\beta .{ }^{39}$ Therefore, it is likely that $4-1 \mathrm{BBL}^{39}$ is an additional means to generate $\mathrm{CD}^{+}$ regulatory $\mathrm{T}$ cells. This is consistent with observations that 4-1BB and OX40 promote the maintenance of CD4, FoxP3 ${ }^{+}$ regulatory $\mathrm{T}$ cells. ${ }^{41}$

Although the direct "conversion" of effector T cells to a regulatory phenotype can be accomplished in hours in vitro, the generation of some regulatory $\mathrm{T}$ cells in vivo may take days if some effector $\mathrm{T}$ cells generated during an immune response are then converted to a suppressive phenotype. Therefore, the environment may influence the induction of regulatory $\mathrm{T}$ cells or macrophages that induce regulatory $\mathrm{T}$ cells. For example, $\mathrm{F} 4 / 80^{+}$monocytes in the anterior chamber are converted to a regulatory phenotype that induces antigen-specific regulatory $\mathrm{T}$ cells by TGF- $\beta$ in aqueous humor. ${ }^{3,42}$ Effector cells that encounter these monocytes in the anterior chamber are probably converted to a suppressive phenotype.

\section{Cytokines and regulatory function of $\mathrm{CD}^{+}$, FoxP3 ${ }^{+}$regulatory $\mathrm{T}$ cells}

The effector mechanisms of $\mathrm{CD}^{+}{ }^{+}, \mathrm{FoxP}^{+}{ }^{+}$regulatory $\mathrm{T}$ cells are controversial. It appears unlikely that some Tregs function via the secretion of anti-inflammatory cytokines such as TGF- $\beta$ or IL-10. However, since T cells resistant to TGF- $\beta$ are not suppressed by $\mathrm{CD}^{+}, \mathrm{FoxP}^{+} \mathrm{Treg}^{38}$ Treg may not secrete TGF- $\beta$, but present this cytokine as a membrane protein. $\mathrm{CD}^{+}$, FoxP3 ${ }^{+} \mathrm{T}$ regulatory cells found in fat tissue suppress effector T cells via IL-10. ${ }^{43}$ Given various suppressive mechanisms, it is likely that $\mathrm{CD} 4^{+}$regulatory $\mathrm{T}$ cells,

Table 2 Cytokines required for regulatory $T$ cell activation, maintenance or function

\begin{tabular}{|c|c|c|c|c|c|}
\hline \multirow[t]{3}{*}{ Cytokine } & \multicolumn{2}{|c|}{ Induce/maintain } & \multicolumn{2}{|c|}{ Required for regulatory function } & \multirow{3}{*}{$\begin{array}{l}\text { Induce } \\
\text { Regulatory } \\
\text {-macrophage }\end{array}$} \\
\hline & \multicolumn{2}{|c|}{ Regulatory $\mathrm{T}$ cells } & \multicolumn{2}{|c|}{ Regulatory $\mathrm{T}$ cells } & \\
\hline & CD4 ${ }^{+}$FoxP3 & $\mathrm{CD8}^{+}$ & $\mathrm{CD4}^{+} \mathrm{FoxP3}^{+}$ & $\mathrm{CD8}^{+}$ & \\
\hline TGF- $\beta$ & $++^{30}$ & $t^{31,32}$ & $+t^{38}$ & $t^{31,39}$ & $t^{3,7,35}$ \\
\hline IL-10 & $+t^{35}$ & $t^{51}$ & $+/{ }^{43}$ & $+/-^{35,44}$ & $+^{42,51}$ \\
\hline IL-2 & $+^{30}$ & N.T. & N.T. & N.T. & N.T. \\
\hline IFN- $\gamma$ & - & - & - & $+^{34,46}$ & - \\
\hline $4-I B B L$ & N.T. & $t^{39,41}$ & - & - & N.T. \\
\hline
\end{tabular}

Notes: References in brackets

Abbreviations: NT, not tested, IL, interleukin 
depending on whether they are induced or "natural," may suppress by different mechanisms.

\section{$\mathrm{CD}^{+}$regulatory $\mathrm{T}$ cells}

Because there are several types of $\mathrm{CD} 8^{+}$regulatory $\mathrm{T}$ cells, ${ }^{44}$ it is likely that this diverse group of cells has several suppressive mechanisms and external influences on function. $\mathrm{CD} 8^{+}$ regulatory $\mathrm{T}$ cells induced by culture with agonist antibodies to $4-1 \mathrm{BB}^{39}$ or induced by the injection of antigen into the anterior chamber of the eye ${ }^{37}$ produce TGF- $\beta$ and use this cytokine as a suppressive mechanism. Suppression effected by $\mathrm{CD}^{+}$regulatory $\mathrm{T}$ cells is not bystander suppression. ${ }^{45}$ Therefore, it is likely that this antigen-specific suppression is effected in the immediate environment of the cells being suppressed (cell contact?). $\mathrm{CD} 8^{+}$regulatory $\mathrm{T}$ cells recovered from interferon (IFN)- $\gamma-/-$ mice do not suppress antigeninduced proliferation by immunized T cells in vitro ${ }^{39}$ or the DTH reaction in immunized mice unless IFN- $\gamma$ is provided to the regulatory T cells. ${ }^{46}$ However, IFN- $\gamma$ does not suppress the DTH reaction. The mechanism of this requirement for IFN- $\gamma$ is not known. Because the $\mathrm{CD} 8^{+}$effector function of the regulatory $\mathrm{T}$ cells is restricted by the expression of Qa-1 by the effector cells, ${ }^{47}$ perhaps IFN- $\gamma$ influences the expression of effector cell Qa-1 or the receptor for Qa-1 that is expressed and required by the CD 8 regulatory $\mathrm{T}$ cells.

\section{Resistance to suppression}

In 1981, a resistance to adaptive (cell-mediated) immunosuppression was described as "contrasuppression." 48 The notion of a resistance to suppression was met, at that time, with some derision. In fact, the entire area of adaptive immunoregulation fell by the scientific wayside until the description of $\mathrm{CD}^{+}$, Fox $3^{+}$regulatory $\mathrm{T}$ cells. ${ }^{30,49}$ That there may be resistance to suppression has received attention more recently. It is evident that cytokines exert a strong influence on the activation and/or function of many regulatory $\mathrm{T}$ cells. Indeed, these cells are often a product of an immune response. In that regard, the SNS will also influence the activation and/or function of regulatory T cells since the SNS exerts a strong influence on various cellular and physiological aspects of an immune response. Accordingly, a downregulation of the SNS may mitigate some aspects of adaptive immunoregulation. In contrast, upregulation of the SNS, as occurs in an acute sympathetic response, (that would occur in a "fight or flight" response), enhances a cell-mediated immune response. ${ }^{50} \mathrm{In}$ addition to a direct influence on regulatory $\mathrm{T}$ cells, cytokines and the environment may also affect the susceptibility of effector $\mathrm{T}$ cells to suppression. Thus, the so-called "tuned suppression" ${ }^{51}$ would have a strong impact on an immune response. As described above, some $\mathrm{CD} 8^{+}$regulatory $\mathrm{T}$ cells effect suppression by the production of TGF- $\beta$. Mice resistant to TGF- $\beta$ due to a lack of a functional receptor or ubiquitin ligase are resistant to suppression by $\mathrm{CD}^{+}$, $\mathrm{FoxP}^{+}$Treg or $\mathrm{CD} 8^{+}$regulatory $\mathrm{T}$ cells induced via the injection of antigen into the anterior chamber. ${ }^{37,38}$ Therefore, any agent that inhibits TGF- $\beta$ signaling, or blocks the receptor for TGF- $\beta$ will likely render an effector cell resistant to suppression by these cells. We have observed the generation of resistance to the suppression of a DTH reaction, mediated by $\mathrm{CD}^{+}$suppressor $\mathrm{T}$ cells, induced by the injection of antigen into the anterior chamber of an eye. The presence of T cells resistant to suppression is consistent with the suggestion that such resistance could occur in autoimmunity. ${ }^{51}$

\section{Coda}

At the outset we emphasized that the immune system militia is highly regulated by the SNS and by the immune system itself(Figure 1). The peripheral SNS has a profound influence on immune homeostasis by participating in the maintenance and activation of T cells that regulate both humoral and cellmediated immune responses. SNS neuropeptides such as neuropeptide $\mathrm{Y}$ and NE promote the production of IFN- $\gamma$ that is required by $\mathrm{CD}^{+}$suppressor $\mathrm{T}$ cells to effect suppression. The SNS either regulates the production of TGF- $\beta$ via NE or produces this cytokine. TGF- $\beta$ produced by other cells, influenced by the SNS or perhaps derived from the SNS, may convert effector $\mathrm{T}$ cells to a suppressor phenotype. In addition, NE-dependent NKT cells that participate in the induction of $\mathrm{CD} 8^{+}$suppressor $\mathrm{T}$ cells require an intact SNS. In aggregate, the SNS and the immune system interact to provide the homeostasis necessary for defense and the prevention of autoimmunity.

\section{Disclosures}

The authors report no conflicts of interest.

\section{References}

1. Jiang H, Chess L. An integrated model of immunoregulation mediated by regulatory T cell subsets. Adv in Immunol. 2004;83:253-288.

2. Shevach EM. From vanilla to 28 flavors: multiple varieties of T regulatory cells. Immunity. 2006;25:195-201.

3. Cone RE, Chattopadhyay S. Control of delayed-type hypersensitivity by ocular-induced $\mathrm{CD}^{+}$regulatory T cells. Chem Immunol Allergy. 2008;94:138-149.

4. Smith TRF, Kumar V. Revival of $\mathrm{CD}^{+}$Treg-mediated suppression. Trends in Immunology. 2008;29:337-342.

5. Gershon RK, Kondo K. Infectious immunological tolerance. Immunology. 1971;21:903-14. 
6. Green D, Flood PM, Gershon RK. Immunoregulatory T cell pathways. Ann Rev. Immunol. 1983;1:439-463.

7. Streilein JW. Immune regulation and the eye: a dangerous compromise. FASEB Journal. 1987;1:199-208.

8. Bour-Jordan H, Bluestone JA. Regulating the regulators: costimulatory signals control the homeostasis and function of regulatory $\mathrm{T}$ cells. Immunol Rev. 2009;229:41-66.

9. Goetzl EJ, Chan RC, Yadav M. Diverse mechanisms and consequences of immunoadoption of neuromediator systems. Ann N Y Acad Sci. 2008; 1144:56-60.

10. Madden KS, Sanders VM, Felten DL. Catecholamine influences and sympathetic neural modulation of immune responsiveness. Annu Rev Pharmacol Toxicol. 1995;35:417-448.

11. Wrona D. Neural-immune interactions: an integrative view of the bidirectional relationship between the brain and immune systems. J Neuroimmunol. 2006;172:38-58.

12. Elenkov IJ, Wilder R, Chrousos GP, Vizii ES. The sympathetic nervean integrative interface between two supersystems: the brain and the immune system. Pharm Rev. 2000;52:595-638.

13. Shepherd AJ, Downing EG, Miyan JA. Without nerves, immunology remains incomplete-in vivo veritas. Immunology. 2005;116:145-163.

14. Madden KS, Stevens SY, Felten D, Bellinger DL. Alterations in $\mathrm{T}$ lymphocyte activity following chemical sympathectomy in young and old Fischer rats. J Neuroimmunol. 2000;103:131-145.

15. Madden KS, Felten SY, Felten DF, Sundaresan PR, Livnat S. Sympathetic neural modulation of the immune system. Brain Behav Immun. 1989;3:72-83.

16. Kruszewska B, Felten SY, Moynihan JA. Alterations in cytokine and antibody production following chemical sympathectomy in two strains of mice. J Immunol. 1995;155:4613-4620.

17. Li X, Taylor S, Zegarelli B, Shen S, O'Rourke J, Cone RE. The induction of splenic suppressor T cells through an immune-privileged site requires an intact sympathetic nervous system. Immunology. 2004;153:40-49.

18. Bhowmick S, Singh A, Flavell RA, Clark R, O'Rourk J, Cone RE. The Sympathetic Nervous system modulates $\mathrm{CD}^{+}{ }^{+} \mathrm{FoxP} 3^{+}$regulatory T cells via a TGF- $\beta$-dependent mechanism. J Leuk Biology. 2009;86:1275-1283.

19. Callahan TA, Moyninhan JA. Contrasting patterns of cytokines in antigen-versus mitogen-stimulated splenocyte cultures from chemically denervated mice. Brain Behav Immun. 2002;16:764-773.

20. Andrade-Mona CE. Inhibition of gamma interferon synthesis by catecholamines. J Neuroimmunol. 1997;76:10-14.

21. Khalil Z, Helme RD. Sympathetic neurons modulate plasma extravasation in the rat through a non-adrenergic mechanism. Clin Exp Neurol. 1989;26;45-50.

22. Karpus WJ, Konkol RJ, Killen JA. Central catecholamine neurotoxin administration.1. Immunological changes associated with the suppression of experimental autoimmune encephalomyelitis. J Neuroimmunol. 1988; 18:61-73

23. Trop S, Samsonov D, Gotsman I, Alper R, Diment J, Ilan Y. Liverassociated lymphocytes expressing NK1.1 are essential for oral immune tolerance induction in a murine model. Hepatology. 1999; 29:746-755.

24. Minagawa M, Kova H, Yamamoto S, et al. Intensive expansion of natural killer $\mathrm{T}$ cells in the early phase of hepatocyte regeneration after partial hepatectomy in mice and its association with sympathetic nerve activation. Hepatology. 2000;31:907-915.

25. Sonoda K-H, Exly M, Snapper S, Bulk ST. Stein-Streilein J. CD-1-reactive natural killer T cells are required for the development of systemic tolerance through a privileged site. J Exp Med. 1999; 180:1215-1226.

26. Vega J, Keino H, Masli S. Surgical denervation of ocular sympathetic afferents decreases local transforming growth factor- $\beta$ and abolishes immune privilege. Am J Path. 2009;175:1218-1225.

27. Wheway J, MacKay CR, Newton RA, et al. A fundamental bimodal role for neuropeptide Y1 receptor in the immune system. $J$ Exp Med. 2005;202:1527-1538.
28. O'Rourke J, Jiang X, Hao Z, Cone RE, Hand AR. Distribution of sympathetic tissue plasminogen activator (tPA) to a distant microvasculature. J Neurosci. 2005;79:727-733.

29. Cosentino M, Fietta AM, Farrari M, et al. Human $\mathrm{CD} 4^{+}$.CD25+regulatory $\mathrm{T}$ cells selectively express tyrosine hydroxylase and contain endogenous catecholamines subserving an autocrine/paracrine inhibitory loop. Blood. 2007;109:632-642.

30. Wan YY, Flavell RA. Yin-Yang functions of Transforming growth factor $\beta$ and $\mathrm{T}$ regulatory cells in immune regulation. Immunol Rev. 2007;222:199-213.

31. Menoret A, Myers LM, Lee S-J, Mittler RS, Rossi RJ. Vella AT. TGF- $\beta$ protein processing and activity through TCR triggering of primary $\mathrm{CD} 8^{+} \mathrm{T}$ regulatory cells. J Immunol. 2006;177: 6091-6097.

32. Kapp JA, Honjo K, Kapp LM, Xu XY, Cozier A. Bucy R. TCR transgenic $\mathrm{CD} 8^{+} \mathrm{T}$ cells activated in the presence of TGF- $\beta$ express FoxP 3 and mediate linked suppression of primary immune responses and cardiac allograft rejection. Int Immunol. 2006;18:1549-1562.

33. Kezuka $\mathrm{T}$ Streilein, JW. In vitro generation of regulatory $\mathrm{CD} 8^{+}$ $\mathrm{T}$ cells similar to those found in mice with anterior chamberassociated immune deviation. Invest Ophthalmol Vis Sci. 2000; 41:1803-1811.

34. La Cava A. Tregs are regulated by cytokines: implications for autoimmunity. Autoimmunity Reviews. 2008;8:83-87.

35. Suciu-Foca N, Manavalan JS, Cortesini R. Generation and function of antigen-specific suppressor and regulatory T cells. Transplant Immunol. 2003;11:235-244.

36. Stein-Streilein J, Taylor AW. Eye's view of T regulatory cells. J Leukocyte Biol. 2007;81:593-598.

37. Cone RE, Chattopadhyay $S$, Sharafieh $R$, et al. $T$ cell sensitivity to TGF- $\beta$ is required for the effector function but not the generation of splenic $\mathrm{CD} 8^{+}$regulatory $\mathrm{T}$ cells induced via the injection of antigen into the anterior chamber. Internat Immunol. 2009;21: 567-574.

38. Wohlfert EA, Clark RB. "Vive la Resistance!"-the PI3K-Akt pathway can determine target sensitivity to regulatory $\mathrm{T}$ cell suppression. Trends in Immunol. 2007;28:154-160.

39. Myers L,Croft M, Kwon BS, Mittler RS, Vella AT. Peptide-specific CD8 T regulatory cells use IFN-gamma to elaborate TGF-beta-based suppression. J Immunology. 2005;174:7625-7632.

40. Jiang L, He H, Yang P, et al. Splenic $\mathrm{CD}^{+} \mathrm{T}$ cells secrete TGF- $\beta$ to exert suppression in mice with anterior chamber-associated immune deviation. Graefes Arch Exper and Clin Ophth. 2009; 247:85-92.

41. So T, Lee S-W, Croft M. Immune regulation and control of regulatory T cells by OX40 and 4-1BB. Cytokine Growth Factor Reviews. 2008;19:253-262.

42. Niederkorn JY. Immune privilege in the anterior chamber of the eye. Crit Reviews in Immunol. 2000;11:13-46.

43. Feuerer M, Herrero L, Cipolletta D, et al. Lean, but not obese, fat is enriched for a unique population of regulatory $\mathrm{T}$ cells that affect metabolic parameters. Nature Medicine. 2009;15(8):930-939.

44. Smith T, Kumar V. Revival of CD $8^{+}$Treg-mediated suppression. Trends in Immunology. 2008;29:337-342.

45. Cone RE, Chattopadhyay S, Sharafieh R, Lemire Y, O'Rourke J. The suppression of hypersensitivity by ocular-induced CD8(+) T cells requires compatibility in the Qa-1 haplotype. Immunol and Cell Biol. 2009;87:241-248.

46. Cone RE, Li X, Sharafieh R, O’Rourke J, Vella AT. The suppression of delayed-type hypersensitivity by $\mathrm{CD} 8^{+}$regulatory $\mathrm{T}$ cells requires interferon-gamma. Immunology. 2007;120:112-119.

47. Chattopadhyay S, O'Rourke J, Cone RE. Implication for the CD94/ NKG2A-Qa-1 system in the generation and function of ocular-induced splenic CD8+ regulatory T cells. Int Immunol. 2008;20:509-516.

48. Gershon RK, Eardley DD, Durum S, et al. Contrasuppression. A novel immunoregulatory activity. J Exp Med. 1981;153:1533-1546. 
49. Sakaguchi S. Regulatory T cells: key controllers of immunologic selftolerance. Cell. 2000;101:455-458.

50. Dhabar FS, Saul AN, Daugherty C, Holmes TH, Boulley DM, Oberyszyn TM. Short-term stress enhances cellular immunity and increases early resistance to squamous cell carcinoma. Brain Behavior and Immunity. 2010;24:127-137.
51. Walker LSK. Regulatory T cells overturned: effectors fight back. Immunology. 2009;126:466-474.

International Journal of Interferon, Cytokine and Mediator Research

\section{Publish your work in this journal}

The International Journal of Interferon, Cytokine and Mediator Research is an international, peer-reviewed, open-access, online journal. The focus of the journal is to publish original research, reports, editorials, reviews and commentaries on all aspects of interferon, cytokine and mediators of inflammation from labora- tory science to therapeutic indications and clinical studies. The manuscript management system is completely online and includes a very quick and fair peer-review system, which is all easy to use. Visit http://www.dovepress.com/testimonials.php to read real quotes from published authors.

Submit your manuscript here: http://www.dovepress.com/international-journal-of-interferon-cytokine-and-mediator-research-journal 